\title{
Performativity of Gender and Sexualities: The Implications in the Education of Youths
}

\author{
Cleber Gibbon Ratto ${ }^{1}$, Carla Lisbôa Grespan ${ }^{2}$, Miriam Pires Corrêa de Lacerda ${ }^{3}$ \\ ${ }^{1}$ Sponsored by CNPq Productivity. Assistant Coordinator of the Graduate Program in Education UNILASALLE, \\ Canoas, Brazil \\ ${ }^{2}$ Sponsored by CNPq. Ph.D. Student of the Graduate Program in Education UNILASALLE, Canoas, Brazil \\ ${ }^{3}$ Adjunct Professor of the Graduate Education of the Pontifical Catholic University of Rio Grande do Sul \\ Program, Porto Alegre, Brazil \\ Email: cleber.ratto@unilasalle.edu.br, carla.grespan@ufrgs.br, miriam.lacerda@pucrs.br
}

Received 4 May 2016; accepted 18 July 2016; published 22 July 2016

Copyright (C) 2016 by authors and Scientific Research Publishing Inc.

This work is licensed under the Creative Commons Attribution International License (CC BY).

http://creativecommons.org/licenses/by/4.0/

c) (i) Open Access

\section{Abstract}

This article aims to discuss the possibilities of bringing about gender and sexuality Performativities Policies in schools through dialogue between the Post-Structuralists Theories and Feminist and Queer Studies and the data presented in the report "Project on the Discriminatory Actions in School Scope", which included a quantitative study through a survey applied in 500 schools throughout Brazil with the specific purpose of assessing the perceptions of the school community in relation to situations of violence in the school and family environment, the incidence and intensity race discrimination situations, ethnicity, gender and sexual orientation and the recognition and respect for diversity; and the "Agenda Youth Brazil", which is one of the strategic actions of the National Youth Secretariat (SNJ), aims to meet the demands, opinions and social, cultural, political and demographic of Brazilian youths, recognizing them as rights holders and public policy. The Performativities Policies has been building in the cracks and should be the agenda in discussions of everyday school life so that they can produce practices that eliminate discrimination, resulting in humiliation and aggression (psychological and physical). One of these spaces of discussion is undoubtedly, the curriculum, we know your political potential, by understanding it as a text in which language constructs are viscerally involved in the production of reality. Thus, we believe that to contemplate the themes linked to citizenship (attitudes and values) and to respect the differences, the curriculum may provide learning conditions in which to recover the experiences of corporeity, of belonging, perceptions, and conceptions of the world, making it a welcome space, equity of rights and opportunities.

\section{Keywords}

Performativities Policies, Education, Youths 


\section{Introduction}

In the history of modern societies, powers/knowledge about sexuality have been produced and guided by process of control and incitement. These processes, while at the same time, broadened the theoretical discussion, they kept their bias homophobic, whether it is through the invisibility of different sexual practices that are not heterosexual, or for the maintenance of the naturalization of the matching process between biological sexgender-sexual practice, the heteronormativity.

In heteronormative process, the social gender ${ }^{1}$ marker crosses the sexuality marker, and has guided the academic productions, especially those related to the area of education that points out the school as a pedagogical instances of constitution of what it is to be female or male of reassurance of the standard roles dictated by society and attitudes that individuals have to take to become included, enhancing the representation of certain groups and putting others on the limit, on the border of invisibility.

The concept and organization of the Brazilian education are based on the heteronormative standards that value and build a person—man, male, white, middle/upper class, young, "healthy" and straight—however in the school routine, such standards are expressed by enunciation and misogynist, sexist and homophobic (lesbophobic and transphobic) behaviors.

This article seeks to dialogue having the data presented in a report as a study project called The Discriminatory Actions in School Scope ${ }^{2}$ and Agenda Youth Brazil ${ }^{3}$ with the theoretical assumptions of Post-Structuralist Theories, Feminist and Queer Studies aiming to point out the possibilities of enabling policies of performativities of gender and sexuality in schools.

\section{School and Youth: The Crossing of Genders and Sexualities}

The Study Project on the Discriminatory Actions in School Scope was a survey conducted in 2008 by the National Institute of Educational Studies and Research (INEP) in partnership with the Economic Research Institute Foundation (FIPE), which included a quantitative study, by a survey ${ }^{4}$ applied in 500 schools across the country having as targeting audience:

- 501 principals

- 1005 teachers who teach Portuguese and mathematics in elementary and high schools

- 1004 employees such as: Secretaries/porters/counselors, cooks/or the like

- 15,087 students of the final years of elementary school, High school or EJA ${ }^{5}$

- 1002 fathers/mothers/responsible for the students of the aforementioned series, which are members of the School Board or the Association of Parents and Teachers.

Considering the topics covered in the research: Gender, ethnic-racial, socioeconomic, generational, people with disabilities, territoriality and sexual orientation have been defined as specific objectives to evaluate the perceptions:

- Situations of violence in the school and family environment, especially psychological violence, physical and sexual abuse and exploitation, and their impact in terms of attitudes and behavior of victimized people;

- The incidence and intensity of discriminatory situations, regarding race, ethnicity, gender and sexual orientation, or, in situations of conflict with the law of the various target populations of the study;

- The recognition and respect for diversity.

The results of this research were presented in 2009 in a report

in order to characterize the study sample due to the demographic profile of the respondents describe the behaviors, attitudes, beliefs and values of respondents about the different studied aspects that make up the thematic areas of prejudice and discrimination addressed in this study (ethno racial, disability, gender,

\footnotetext{
${ }^{1}$ Aligned to Meyer (2004: p. 15) we consider that gender refers to all forms of social, cultural and linguistic having to do with processes that differ women from men, including those processes that produce their bodies, distinguishing them and naming them as bodies containing sex, gender and sexuality.

${ }^{2}$ Report presented in 2009 and the result of an agreement signed in 2008 between the National Institute of Educational Studies and Research (INEP) and the Economic Research Institute Foundation (FIPE). http://portal.mec.gov.br/dmdocuments/relatoriofinal.pdf.

${ }^{3}$ National research profile and opinion of young Brazilians 2013.

https://issuu.com/participatorio/docs/agenda_juventude_brasil___pesquisa_/1?e=12152407/10902032.

${ }^{4} \mathrm{~A}$ survey research is defined as a "collection of information on the characteristics, actions or opinions on a large group of people, such as a population”. (Tanurapud Pinsonneault e Kraemer, 1993: p. 3)

${ }^{5}$ Teaching young people and adults.
} 
generational, socio-economic, territorial and sexual orientation) and evaluate integrative and simultaneously, through multivariate statistical methods, the interrelationship between the observed variables and dimensions or inferred constructs that make up the aforementioned thematic areas. (Brazil, 2009: p. 52)

Unlike previous research Agenda Youth Brazil, held in 2013, is one of the strategic actions of the National Youth Secretariat (SNJ), which has as one of its guidelines the recognition of young ${ }^{6}$ people as subjects of rights and public policy. From this point, it is necessary to meet the demands, opinions and social, cultural, political and demographic realities of the Brazilian youths, not only through the their profile "but mainly to accompany the behavioral tendencies and beliefs of young people, identify the demands for public policies and measure the resonance of some ongoing responses”. (Brazil, 2014: p. 11)

The survey was conducted between April and May 2013, through personal and household interviews with 3300 people between 15 - 29 years of 187 municipalities in 27 states, covering capital and countryside, urban and rural areas, small, medium and large towns. This sample, a cut of internal age groups was made-15 to 17 , 18 to 24 and 25 to 29 years old — justified the adoption of this parameter by public policies in the country.

The interviews were structured in eight large thematic blocks containing 161 questions and average time of one hour of application. The final research report subdivides the data in the same thematic blocks of the interviews:

1) Profile and Youth Condition: youth and age, sex, color, religion, young people from rural and urban areas, family structure, socioeconomic status, education, activity status;

2) Information and Communication Technology: Computer use, forms of use and Internet access locations; use purposes of the Internet and mobile;

3) School and Vocational Training: educational experience, perceptions of school, vocational training, technical or vocational courses;

4) The world of work: the first job; work and age, formality at work, working hours, job search, young people who do not work, the world of work perceptions;

5) Violence against Black Youth: experiences of discrimination;

6) Youth Issues and Country Perceptions: personal fulfillment, which are the problems that most concern young people today, different areas to discuss the issues, Brazil's problems that bother them most, what young people value the most in Brazil, expectations of life, to the country and the guarantee of rights, values considered fundamental by young people;

7) Political Life: politics is important, voter registration, young people can change the world, appreciation of forms of action and degree of participation;

8) Policies for Youth: the government's actions for youth, political knowledge among young people, priorities of government action, actions to confront violence, best policy to face violence in the country, health policy, more and better policies.

In this article the data to be analyzed are related to the descriptors: young people-Youth-school-gender-sexuality. In addition, as age average to young people we will follow the Law No. 12852, of 5 August 2013, the Statute of Youth, in paragraph 1 of his article 1, which provides:

This law establishes the Youth Statute and provides for the rights of young people, the principles and guidelines of public policies for youth and the National Youth System (Sinajuve).

$\S 1$ For the purposes of this law, people aged between fifteen and twenty-nine are considered Young.

Modern society attributes to some institutions, the authority to define, delimit and shape the normal standard of purity or health, among those the school has fulfilled its role of control of the youths in the exercise of pleasure, the chances of experiencing genres, to transform and live the bodies.

The discourse on gender and sexuality produced and reproduced at school aim to encourage and enhance the representation of certain subjects, ignoring others, depositing them in in the limit, at the border. When the school institution puts the heteronormative process in place makes it impossible for the performativitie ${ }^{7}$, gender and sexuality policies, making the life of some people in the school community, more difficult to be lived.

This way, some possible correlations and analysis of the data found in these two studies are of pivotal impor-

\footnotetext{
${ }^{6}$ According to Article 227 of the Brazilian Constitution, the Youth Statute and the 2010 Census, young people/youth segment/youth comprehend the age group 15 - 29 years.

${ }^{7}$ Butler argues that "gender identity and sexual identity are produced by repeated performative enunciation. In other words, cultural identity in general is a matter of performativity" (Silva, 2000: pp. 90-91).
} 
tance for the construction of pedagogical practices that check the multiple possibilities of genders and sexualities promoting the reduction of violence (physical, mental and moral) against women and people LGBT (IQ) Lesbian, Gay, Transgender/Transsexual (Intersex and Queer), respect and gender equality.

\section{Performativities of Genders and Sexualities}

The nineteenth century named, and meant and mainly normalized the sexuality. According to Foucault (1988), it is a "historic apparatus"; it is the story of speeches that have made sexuality a body of knowledge developed to organize, modeling bodies and controlling behavior, creating the "knowledge about pleasure" and "pleasure of knowing." Here comes the deviation of the standard, men and women who challenged heteronormativity ${ }^{8}$, the homosexual person.

This process that produced the homosexual individuals serves as a marking of difference system "that separates an identity of another, by distinguishing, often in the form of opposites”, forming a classificatory and social hierarchy system in contemporary Western culture is established in a binary thinking-homosexual/heterosexual, male/female, white/black, poor/rich, "normal"/different (Woodward, 2007: p. 41).

The differentiation system demarcates the boundaries between the "standard" and "deviation", nominates the "normal" as the center and the "different" as the margin is an engine of the process of meaning that occurs within the networks of power/knowledge causing the "different" to have a negative classification, aiming to fix and stabilize "the identity" as hegemonic.

The creation of these identity borders does not prevent the subject to exceed them, it is necessary to put the heteronormativity process into practice. As explained Louro,

The monitoring turns, explicitly to the bodies. A surveillance that is carried out not only from the outside, the obedience to the rules, to the precepts or codes, but which is exercised by the individual that early, learns to examine, control, govern. (Louro, 2000: p. 69)

The body becomes the great social marker in contemporary times, it is the operator of a process of differentiation. The way of living and use the body implies in a choice-taking over, interpreting, producing many styles and organizing the rules. Flexible, mutant, transient, it is historic and when it begins to carry the burden of the fixed identity and it crystallizes an image in time and space, creating a social representation. Thus, body practices constitute relations of knowledge/power, which produce multiple discourses of being in the world.

The discourses seek in the supposed biologicist, essence in order to secure and stabilize the individuals in a hegemonic identity discriminate against their bodies and their practices of gender and sexualities. For Foucault (1988), the Sexuality device was introduced to produce true discourses on sex, from the effects of this device is the gendered body experience, that is, the power/knowledge on the body produce the discourse of the true man, the real woman.

The Post-Structuralist Theories, Feminist Studies and, above all, Queer Studies ${ }^{9}$, dissociate the alleged linear order between sex, gender and sexual desire and allow another look on gender relations and sexuality. These studies put on the agenda the discussion of the social and biotechnological transformation of the body, their attributes, their feelings and desires, in the center of interest of academic productions. In addition, they point the body as the weakest point on the power devices and subjectivity that regulate genders, sexualities and violence from organic labels in restricting identity and heteronormative categories. This is what Butler (2015) calls the rules of gender violence.

Brazilian education was conceived and organized according to the heteronormativity standards, valuing and building the adult male, white, middle-class and heterosexual. Such standards are accompanied by their utterances and behaviors that express homophobia and sexism, the results presented in the research for the construction of teaching to combat homophobia practices, sexism and misogyny in schools are important.

\footnotetext{
${ }^{8}$ For Santos (2011) heteronormativity results of the approach of two other known words and commonly used in our culture: straight and standard. Straight comes from the Greek and refers to different. When we talk about sex we refer to heterosexual to say those who have "affinity, attraction and/or behaviors of individuals of different sexes" (apud SANTOS FERREIRA, 1999: p. 1040). Standards direct us to the territory that is considered "a basis or measure for evaluating something" (ibid) also concerning the conduct, model, pattern. Thus, heteronormativity combines at the same time, heterosexuality and patterns considered legitimate. In other words, it is "a pattern of sexuality that has the quality or strength of a standard” (SANTOS, 2009: p. 44).

${ }^{9}$ In the words of Steven Seidman a sociologist, Queer would be the study “of that knowledge and those social practices that organize the 'society' as a whole, sexualizing-heterossexualizing or homossexualizing-bodies, acts desires, identities, social relations, knowledge, culture and social institutions.” (Miskolci apud Seidman, 2009: p. 154).
} 


\section{Gender Relations and Sexuality: Social Markers in Research Involving Youths}

The "Study Project on Discriminatory Actions in School Scope” held in 501 Brazilian schools produced a database to be analyzed had as

Purpose to characterize the study sample due to the demographic profile of the respondents describe the behaviors, attitudes, beliefs and values of respondents about the different studied aspects that make up the thematic areas of prejudice and discrimination addressed in this study (ethnic-racial, people with special needs, gender, generational, socio-economic, territorial and sexual orientation) and evaluate in an integrative and simultaneous way through multivariate statistical methods, the interrelationship between the observed variables and dimensions or inferred constructs that make up the aforementioned thematic areas.

(Brazil, 2009: p. 53)

In this article we have the youths as analytical approach and with regard to the age structure of the respondents less than 30 years of age make up $6.8 \%$ of directors of schools, $20 \%$ of teachers $17.3 \%$ of employees, $6.1 \%$ of fathers/mothers/guardians and $86 \%$ of students is presented in Table 1 . Thus, we have analyzed the data of the students those distributed quantitatively by regions as follows: the Southeast $41 \%$ (5319), the Northeast 30\% (3892), South 12\% (1556), North 10\% (1297) and Midwest with just over 7\% (908), focusing on the themes of gender and sexuality, show as Table 2 (Brazil, 2009: p. 56).

Issues related to the attitudes of prejudice and knowledge of situations of discrimination witnessed at school (bullying) that composed the questionnaire of the survey were compiled from phrases and expressions voiced in focus groups, and the results indicate that:

prejudice is an element effectively present in the environment of public schools in the country. It is important to note that among the surveyed public, staff, parents, and especially students, are those with the highest levels of prejudice, expressed through their attitudes towards searched phrases. (Brazil, 2009: p. 69)

The phrases were organized in thematic areas ${ }^{10}$-racial ethnic, disability, gender, generational, socio-economic, territorial and sexual orientation-and showed that the highest percentages of discrimination and bullying are related primarily to gender relations (39\%) and in fourth place comes sexual orientation (26.7\%), is presented in Table 3.

Table 1. Distribution of respondents $<30$ years of ages.

\begin{tabular}{ccc}
\hline Respondents & Total & Total $<30$ years \\
\hline Principals & 501 & 34 \\
Teachers & 1.005 & 201 \\
Employees & 1.004 & 173 \\
Students & 15.087 & 12.974 \\
Fathers/Mothers/Responsible & 1.002 & 61 \\
\hline
\end{tabular}

Source: Brazil, 2009: p. 56.

Table 2. Distribution of student's respondents by regions.

\begin{tabular}{ccc}
\hline Region & Total <30 years \\
\hline North & 1.297 & 3.892 \\
Northeast & 908 & 5.319 \\
Midwest & Southeast & 1.556 \\
\hline
\end{tabular}

Source: Brazil, 2009: p. 56.

${ }^{10}$ Brazil, 2009: p. 115. 
Table 3. Phrases that express $>(\%)$ prejudice.

\begin{tabular}{|c|c|c|}
\hline Prejudice & Phrases & Percentage \\
\hline \multirow{4}{*}{ Sexual Orientation } & "Teachers who are not gay are more respected by the students." & $44.9 \%$ \\
\hline & "I find it very difficult to accept the male homosexuality." & $36.4 \%$ \\
\hline & "Do not avoid, but do not try to get close to homosexuals." & $35.3 \%$ \\
\hline & "A lesbian is more accepted in school than a gay man." & $34.2 \%$ \\
\hline \multirow{4}{*}{ Gender } & "A woman is more skilled to take care of the house." & $60.6 \%$ \\
\hline & "Women are better than men in the kitchen." & $52.6 \%$ \\
\hline & "There are jobs that should be performed only by men." & $46.3 \%$ \\
\hline & "There are jobs that should be performed only by women." & $43.4 \%$ \\
\hline
\end{tabular}

Source: Brazil, 2009: pp. 73, 74, 77.

The percentage of knowledge of situations witnessed in school due to discrimination and bullying ${ }^{11}$ (humiliating attitudes, physical assault, unfair charges and other situations) faced by students, teachers and the staff is directly related to the sexual practice and gender issues of these subjects, namely, by his homosexuality and a woman, show as Table 4 and Table 5.

The percentage rates of biased attitude, of social distance and knowledge of the occurrence of bullying situations by gender or sexual orientation, organized by grade level, school size, school location, region of the country and access to the media indicates students agree, first with phrases expressing prejudiced attitudes towards gender and then in relation to sexual orientation is presented in Table 6.

Relating the attitudes of students to the thematic dimensions, the data pointed to higher rates of discrimination and bullying to the dimensions: gender (39\%-1st place) and sexual orientation (26.7\% - 4th place). The same was repeated at the intersection of the data relating sentences thematic dimensions with the corresponding age youths (15 - 29 years of age), show as Table 7.

The group of students who responded to the survey have presented on one side the highest correlation coefficients between discriminatory attitudes and declared knowledge of discriminatory situations in school. And on the other side, smaller correlations between social distance and the awareness of bullying situations. So we can state that the factor with the greatest influence on the awareness of the occurrence of bullying situations in schools is the biased attitude of the students.

The research conclusion points as the most worrying factor

prejudice and discrimination are not likely to result in situations where people are humiliated, beaten and accused unfairly simply because of being part of a particular social group. Note that these discriminatory practices have as main victims the students, especially the black ones, the poor and homosexuals. Despite the fact that students are the biggest victims, discriminatory practices in school also victimize teachers and staff with worrying implications. Among the victimized teachers, those who suffer most from the effects of discriminatory practices, according to the knowledge of the respondents are older teachers, homosexuals and women among employees, the main victims are the poor, the elderly and black people. (Brazil, 2009: p. 352)

Agenda Youth Brazil 2013 is a survey of a single target audience, young people aged between 15 to 29 years, based on the age profile Census 2010 that aimed at youth as equivalent there is 0.25 of the population. Inferring about the extent of age arc justifies the interval parameter age groups- 15 to 17,18 to 24 and 25 to 29 years old-as a parameter adopted by public policies in the country.

The data collected by the survey has as the main objective the identification of the youth demands for the construction of public policies. Thus, there has been a concern to trace the profile, following the behavioral tendencies and the views of the current Brazilian youth, based on the research "Brazilian Youth Profile" 2003, "Youths Brazilian” 2004 and "Youth South American” 2008.

\footnotetext{
${ }^{11}$ Idem, p. 87.
} 
Table 4. Situation of discrimination and bullying at school.

\begin{tabular}{ccccc}
\hline & & \multicolumn{3}{c}{ Reason } \\
\cline { 2 - 5 } Segment & \multicolumn{2}{c}{ Homosexuality } & for being a woman \\
\hline Students & $35.6 \%$ & 1 1st place & $19.2 \%$ & 5th place \\
Teachers & $19.7 \%$ & 2nd place & $15 \%$ & 3rd place \\
Employees & $11 \%$ & 5th place & $13.4 \%$ & 4th place \\
\hline
\end{tabular}

Source: Brazil, 2009: p. 87.

Table 5. Specific situations of bullying at school.

\begin{tabular}{|c|c|c|c|c|}
\hline \multirow{3}{*}{$\begin{array}{c}\text { Physical aggression } \\
\text { Students }\end{array}$} & \multicolumn{4}{|c|}{ Reason } \\
\hline & \multicolumn{2}{|c|}{ Homosexuality } & \multicolumn{2}{|c|}{ For being a woman } \\
\hline & $18.7 \%$ & 3rd place & $14.2 \%$ & 4th place \\
\hline Teachers & $7.7 \%$ & 3rd place & $9.5 \%$ & 1st place \\
\hline Employees & $6.7 \%$ & 2nd place & $7.4 \%$ & 1st place \\
\hline Unfair charges & & Homosexuality & \multicolumn{2}{|c|}{ for being a woman } \\
\hline Students & $15.4 \%$ & 3rd place & $11.1 \%$ & 5th place \\
\hline Teachers & $8.2 \%$ & $3^{\circ} \mathrm{rd}$ place & $8.2 \%$ & 3rd place \\
\hline Employees & $6.8 \%$ & 5th place & $7.5 \%$ & 4th place \\
\hline Contempt or lack of consideration & & Homosexuality & \multicolumn{2}{|c|}{ for being a woman } \\
\hline Students & $25.2 \%$ & 3rd place & $12.7 \%$ & 8th place \\
\hline Teachers & $8.2 \%$ & 3rd place & $8.2 \%$ & 3rd place \\
\hline Employees & $6.8 \%$ & 5th place & $7.5 \%$ & 4th place \\
\hline
\end{tabular}

Source: Brazil, 2009: p. 87.

Table 6. Reactions of students regarding the phrases expressing prejudiced attitudes bullying at school (\%).

\begin{tabular}{|c|c|c|c|c|c|}
\hline & & \multicolumn{4}{|c|}{ Reason } \\
\hline & & \multicolumn{2}{|c|}{ Homosexuality } & \multicolumn{2}{|c|}{ Gender } \\
\hline \multirow{4}{*}{ Grade Level } & Penultimate year of Elementary School & $30 \%$ & 3rd place & $42 \%$ & 1st place \\
\hline & Last year of High School & $23 \%$ & 4th place & $34 \%$ & 2nd place \\
\hline & Elementary Education Modality EJA & $28 \%$ & 5th place & $42 \%$ & 1st place \\
\hline & High School Modality EJA & $24 \%$ & 4th place & $36 \%$ & 2nd place \\
\hline \multirow{3}{*}{ School Size } & Small up to 600 students & $28 \%$ & 4th place & $42 \%$ & 1st place \\
\hline & Average 601 a 1000 students & $27 \%$ & 4th place & $38 \%$ & 1st place \\
\hline & Much more than 1000 students & $25 \%$ & 4th place & $36 \%$ & 2nd place \\
\hline \multirow{3}{*}{ School Location } & Urban area of the capital & $26 \%$ & 5th place & $36 \%$ & 2nd place \\
\hline & Urban area of the country & $27 \%$ & 4th place & $39 \%$ & 1st place \\
\hline & Rural areas & $30 \%$ & 4th place & $43 \%$ & 1st place \\
\hline
\end{tabular}




\begin{tabular}{|c|c|c|c|c|c|}
\hline Continued & & & & & \\
\hline \multirow[t]{5}{*}{ Region of the country } & Southeast & $29 \%$ & 4th place & $37 \%$ & 1st place \\
\hline & Northeast & $29 \%$ & 4th place & $44 \%$ & 1st place \\
\hline & South & $29 \%$ & 4th place & $37 \%$ & 2nd place \\
\hline & North & $27 \%$ & 4th place & $39 \%$ & 1st place \\
\hline & Midwest & $27 \%$ & 4th place & $38 \%$ & 2nd place \\
\hline \multirow[t]{3}{*}{ Access to the media } & very low & $28 \%$ & 4th place & $43 \%$ & 1st place \\
\hline & low & $28 \%$ & 4th place & $41 \%$ & 1st place \\
\hline & high & $24 \%$ & 3rd place & $35 \%$ & 1st place \\
\hline
\end{tabular}

Source: Brazil, 2009: pp. 122, 124, 130, 136.

Table 7. Phrases that express > (\%) prejudice at school.

\begin{tabular}{|c|c|c|c|c|}
\hline Dimensions & Phrase & $\begin{array}{c}\text { Total } \\
\text { percentage }\end{array}$ & $\begin{array}{c}15-19 \\
\text { years }\end{array}$ & $\begin{array}{c}20-29 \\
\text { years }\end{array}$ \\
\hline \multirow{3}{*}{ Gender } & "Domestic work is the task of women." & $56,6 \%$ & $56.1 \%$ & $55.5 \%$. \\
\hline & "There are jobs that can only be performed by a specific genre” & $44.9 \%$ & $44.4 \%$ & $44.2 \%$ \\
\hline & "There are functions in the school that can only be performed by a specific genre.” & $23.3 \%$ & $23.9 \%$ & $22.5 \%$ \\
\hline \multirow{2}{*}{$\begin{array}{c}\text { Sexual } \\
\text { orientation }\end{array}$} & “Non-acceptance of homosexuality” & $37.7 \%$ & $38.7 \%$ & $36.7 \%$ \\
\hline & "Homosexuals should not attend schools with heterosexual environment.” & $18 \%$ & $18.4 \%$ & $14.9 \%$ \\
\hline
\end{tabular}

Source: Brazil, 2009: pp. 181, 182, 197.

Organized in thematic blocks concerning the juvenile condition, education, labor, health (involving the issues of drugs and sexuality), recreation and culture, politics and violence participation, this research was conducted throughout the country, being representative for the urban and rural environment [...] (Brazil, 2014: p. 9)

The clipping of the data we have used since then, research has followed the criteria of the issues surrounding the school institution, gender relations and sexuality, with the crossing of the markers: body, health and violence. From this on, the first relevant data is that the age group of 15 to 17 years old has the most important activity the study with $80 \%$; 18 to 24 years old, the study activities fall sharply to $33 \%$, resulting in the paid activities (work) 54\%; From 25 to 29 years old the most important activity is now the work with $72 \%$ and study activities fall to $14 \%$. The second relevant data that we can make a connection or not with the practice of sexual activity, points out that since the age of 15 to 17 years the young people have already been having active sexual life even though research has only taken as a parameter the marriage and offspring (Brazil, 2014: p. 25).

The variable that relates the geographical location (urban or rural) and the media means, television appears as the first media for both urban and rural youths, respectively $81.4 \%$ and $92.6 \%$ (open TV) and $10.8 \%$ and $1.4 \%$ (closed TV). The Internet appears in second place with $4.9 \%$ and $1.8 \%$, even with such a low percentage compared to television, $80 \%$ of the people interviewed use the computer and /or internet and from those $75 \%$ use both, and 55\% access the network more frequently at home and main end uses social networking sites (social networks) with 56\% of responses (Brazil, 2014: pp. 32-33).

The intersections of education data and have or not a cell identified that respondents who attended Basic Education (Primary and Secondary Education) attended school in public schools (60\% to 70\%). The percentage of young people who have mobile and are studying or have completed primary education ranges from $78 \%$ to $83 \%$, for high school is in the $94 \%$ and higher education reaches $100 \%$. Already relations between education and the mobile use of forms are show in Table 8.

Relating the reasons for interruption of studies according to the biological sex of the young people interviewed we can point out that the lack of desire to study is significant in both cases (30\%); difficulty to council it 
Table 8. Relationship between education and telephone services.

\begin{tabular}{|c|c|c|}
\hline Scholarity & Use of cell & Total percentage \\
\hline Incomplete elementary school & Make and or receive phone calls & $75 \%$ \\
\hline \multirow[t]{2}{*}{ Basic education } & Make and receive phone calls & $79 \%$ \\
\hline & Communicate via text messages/SMS & $53 \%$ \\
\hline \multirow[t]{3}{*}{ Incomplete high school } & Making and or receiving phone calls & $94 \%$ \\
\hline & Communicating via text messages/SMS & $67 \%$ \\
\hline & Listening to music & $40 \%$ \\
\hline \multirow[t]{3}{*}{ High school } & Making and receiving phone calls & $93 \%$ \\
\hline & Communicating via text messages/SMS & $57 \%$ \\
\hline & Listening to music & $31 \%$ \\
\hline \multirow[t]{5}{*}{ Higher education } & Making and or receiving phone calls & $99 \%$ \\
\hline & Communicating via text messages/SMS & $60 \%$ \\
\hline & Seeking information on the Internet & $36 \%$ \\
\hline & Listening to music & $31 \%$ \\
\hline & Connecting to social networks & $25 \%$ \\
\hline
\end{tabular}

Source: Brazil, 2014: p. 29.

with their jobs (5\%) and to taking care of a relative (20\%), it only occurs among women; while only males point discrimination (3\%), the lack of availability (12\%) and marriage (5\%); the lack of money and having to take care of the kids seem to have more importance for men (25\% and $13 \%)$ than for women (5\% and $8 \%)$ (Brazil 2014: p. 43).

Research indicates that $40 \%$ of the young Brazilians have a working journey of 40 hours weekly; "that young men are $25 \%$ more likely to have a formal job than young women”; that women have more difficulties in finding a job due to lack of experience (43\%); and the average of young people who are neither working nor studying "focuses among the young people who are mothers, who have low incomes, and postpone the entry or quit the labor market by restricting their activity to the sphere of reproduction.” (Brazil, 2014: pp. 52, 56).

In the analysis of important issues to be discussed (Table 9) data indicate that the issues involving violence and drugs should be discussed at all levels, possibly for being an issue that's similar to the day by day lives of young people in general and also an issue faced by all the society, but some variations are noted:

the issue of studying and having a future career is the most often mentioned subject as important to be discussed with the family but it only occupies the 6th position as a matter of social relevance. In society it is the theme of inequality and poverty that gained significant relevance, appearing as of little importance to discuss with friends, but not so far from being a priority to discuss with the family. On the other hand, sexuality is frankly a topic to discuss with friends, taking up little space of interest as the theme for the family or society. (Brazil, 2014: p. 73)

The issues proposed to raise the issues that most bother young people identified corruption (67\%), the power of the dealers (46\%), the vast gap between rich and poor (42\%) and racism and other forms of discrimination (34\%), and social inequality appears as a central theme, but the ways of facing them will appear more in young people of poorer conditions. On the other hand these youngsters have mentioned as positive aspects of their country the opportunities to study (63\%) and freedom of expression (55\%) (Brazil, 2014: p. 76).

Regarding expectations for their lives they are more optimistic especially closer to their everyday sphere, as compared to the world they are more pessimistic than optimistic. This is confirmed by the contents of the responses related to Brazil 44\% will improve their neighborhoods increases to $53 \%$ and their lives $94 \%$ due to positive prospects for employment opportunities and education. 
Table 9. Issues that the youth would like to discuss.

\begin{tabular}{|c|c|c|}
\hline With whom? & Issues & Total percentage \\
\hline \multirow[t]{6}{*}{ Parents or guardians } & Education and professional future & $45 \%$ \\
\hline & Violence & $32 \%$ \\
\hline & Drugs & $31 \%$ \\
\hline & Social inequality and poverty & $27 \%$ \\
\hline & Religion & $24 \%$ \\
\hline & Citizenship and human rights & $21 \%$ \\
\hline \multirow[t]{7}{*}{ Friends } & Drugs & $41 \%$ \\
\hline & Sexuality & $31 \%$ \\
\hline & Violence & $30 \%$ \\
\hline & Education and professional future & $29 \%$ \\
\hline & Romantic relationships & $26 \%$ \\
\hline & Racism & $23 \%$ \\
\hline & Arts & $21 \%$ \\
\hline \multirow[t]{8}{*}{ Society } & Social inequality and poverty & $40 \%$ \\
\hline & Drugs & $38 \%$ \\
\hline & Violence & $38 \%$ \\
\hline & Politics & $33 \%$ \\
\hline & Citizenship and human rights & $32 \%$ \\
\hline & Education and professional future & $25 \%$ \\
\hline & Racism & $25 \%$ \\
\hline & Environment and sustainable development & $24 \%$ \\
\hline
\end{tabular}

Source: Brazil, 2014: p. 72.

Questions concerning which elements ${ }^{12}$ are most important to: your present life-family support $75 \%$; to improve life-personal effort 68\%; and to ensure rights-Government policies 47\%. What sets the answers about an ideal world and the values ${ }^{13}$ that they thought were the most important: the fear of God 40\%; respect for differences 39\%; and equal opportunities 33\%, with respect for differences will have a greater weight than the fear of God in the age groups 15 - 17 and 18 - 24, and it is tied at 44\% when we extract data answered by women. And that corroborates the indexes for or against the adoption of children by same-sex couples (51\%) and the reserve of racial and ethnic quotas in universities (56\%).

One factor raised by the research, which is quite relevant regarding sexuality, is on the relationship between income and adoption by homosexual couples, where data indicates that

Young people belonging to the strata of high per capita household income are more strongly opposed to homosexual couples to adopt children than lower income segments. While $42 \%$ of the respondents of rich segments are positioned against the adoption are 36\% of the middle strata and 34\% of low-income young people who share this opinion. Interestingly, the income does not produce significant variation among those who claim to be in favor of the rights of homosexuals. (Brazil, 2014: p. 81)

Another fact that is really emphasized is that the youths do not show interest in forms of association ${ }^{14}$ and political or social participation, those who have never participated represent 54\% and from those $15 \%$ did not par-

\footnotetext{
${ }^{12}$ Brazil, 2014: p. 79.

${ }^{13}$ Idem, p. 80.

${ }^{14}$ Idem, p. 88.
} 
ticipate in associations, organizations and groups, for example: political party (88 \%); cooperative (74\%); entity or group or alternative media free (66\%); consumer protection association (63\%); group or non-religious volunteer association (60\%); entity or movement in defense of discriminated groups (60\%).

The issues surrounding gender relations and sexuality are more emphasized in questions on ways of combating violence and health promotion, where $32 \%$ of the women recommended as one of the ways to tackle violence would be the promotion of disarmament and $97 \%$ of the interviewed people value the public policies for the prevention and/or care for AIDS and sexually transmitted diseases.

\section{Final Considerations}

The analytical relationships that can produce data from these surveys are numerous depending on the thematic clipping and theoretical assumptions used. In this article we will bring the analytical relationships that leave the youths-school-gender-sexuality and the theoretical assumptions Post-Structuralist Theories, Feminist and Queer Studies.

From the data and analysis produced by the Study Project on Discriminatory Actions in School Scope we can infer that the greater weight of the attitudes, beliefs and values that express prejudice refer to thematic areas of gender and sexual orientation; that the greatest weight in the construction of social distance was regarding the social group of homosexuals; that the values of the percentage index of social distance are higher than those for measures of prejudiced attitudes, indicating that they do not accept diversity as they seem to realize and have behavioral intentions that effectively denote discrimination; and bullying in relation to sexual orientation occurs in schools with more students that show lower grades in the evaluations on the Brazil test in 2007.

The discourses that are represented in the speeches and students practice in day-by-day school life make its protagonists more challenged and/or subjugated to gender and sexuality standards. Under the optic of Michel Foucault (2009), the discourse as an active element of the strategies of power-know constructs and conveys representations of the world and its subjects, with the aim of naturalising, classify and prioritize (allowed/prohibited, right/wrong, appropriate/inappropriate, normal/different, included/excluded).

The themes that involve misogyny, sexism and homophobia has a small space in school curriculum and when discussed they are related to bias of health and violence. This stems from the use of biologicist discourses that naturalize lives, fixing a unique identity, a unique possibility to be lived, heterosexuality, reaffirming discriminatory attitudes and bullying in relation to performativities gender and sexualities.

The data of the "Agenda Youth Brazil 2013" although you indicate that one of the positive points of the country is the freedom of expression and that one of the most important values is the respect the differences, many young people still are against adoption of children by homosexual couples; there is no mention of bullying or other violence directed to women and homosexuals.

The theme of sexuality was treated by marriage and procreation bias and gender equity issues were linked to labor relations, or difficulty for women to find employment is linked to lack of experience and/or procreation.

While the survey conducted in 2009 shows that the young people are the ones who suffer the most and produce bullying in school directed to violence and discrimination against women and homosexuals. Since the survey conducted in 2013, caused estrangement as public target the youths, silent on gender equity issues and respect sexualities.

According to Butler (2010), sexuality cannot be understood as pre-discursive, production conditions are necessary in understanding the construction of subjects in line with the construction of the scenario in which they operate. The subjects are constructed and built in a given locus, which is also not given.

Within the binary logic of the couple man-woman, the issues related to homosexuality cause discomfort. The homosexuals are included in the list of abject subjects of aberrations. To Louro (2003) the bodies, as well as sexualities and genders, "are described, understood, explained, regulated, sanitized and educated for many instances, through various tactics, strategies and techniques".

Contemporary culture presents us with a mosaic, new designs and configurations of genders and sexualities that need to be seen as a process of deconstruction and discontinuation of values, truths and structures. The subject embodied is not always the same all the time; the apparatus that builds the body cannot fix it, but it is subjugated, sometimes manages to escape.

And it's in these lines of escaping, and in these cracks that Performativity Policies are built and should be the agenda in discussions of everyday school life so that they can produce practices that eliminate discrimination, resulting in humiliation and aggression (psychological and physical). 
One such discussion areas is undoubtedly the curriculum. When understood as a text in which language constructs are viscerally involved in the production of reality, we cannot ignore the political potential of the same. Designed as a "practical significance" the curriculum opens up other possibilities like seeing and thinking about the world and about the world and, thus, could ensure the production, trading and processing of knowledge conveyed in and by the school.

If we believe so, the school curriculum to contemplate themes related to citizenship (attitudes and values), to respect differences, prioritizing discussions about homophobia, misogyny and sexism, provides learning conditions in which it recovers the experiences of corporeality, of belonging, perceptions and conceptions of the world, becoming the host and reflection of information, questions, values, attitudes and equal rights and opportunities.

\section{References}

Brazil (2009). Study Project on Discriminatory Actions in Schools, Organized According to Thematic Areas, Namely, Ethnic-Racial, Gender, Generational, Territorial, Special, Socioeconomic and Sexual Orientation Needs. Institute of Educational Studies and Research-INEP. Brasília. http://portal.mec.gov.br/dmdocuments/relatoriofinal.pdf

Brazil (2013). Law 12.852. Youth Statute (p. 1). D.O.U., Seção 1. http://www.planalto.gov.br/ccivil_03/_Ato2011-2014/2013/Lei/L12852.htm

Brazil (2014). Agenda Youth Brazil: National Research Profile and Opinion of Young Brazilians. National Youth Secretariat-SNJ. Brasília. https://issuu.com/participatorio/docs/agenda_juventude_brasil___pesquisa_/1?e=12152407/10902032

Butler, J. (2010). Gender Trouble: Feminism and the Subversion of Identity. Rio de Janeiro: Civilização Brasileira.

Butler, J. (2015). Report Yourself: Critique of Ethical Violence. São Paulo: Autêntica.

Foucault, M. (1988). History of Sexuality I: The Will to Knowledge. Rio de Janeiro: Graal.

Foucault, M. (2009). The Order of Things. São Paulo: Loyola.

Louro, G. L. (2000). Body, School and Identity. Educação e Realidade, 25, 59-76, Porto Alegre.

Louro, G. L. (2003). Bodies Escape. Labrys Estudos Feministas. Vol. 4 http://utfpr.edu.br/estrutura-universitaria/pro.../texto-para-o-seminario-tematico

Meyer, D. E. (2004). Theories Gender Policy: Historical Fragments and Current Challenges. Brasília. In: Revista Brasileira de Enfermagem. http://www.scielo.br/pdf/reben/v57n1/a03v57n1.pdf

Miskolci, R. (2009). Queer Theory and Sociology: The Challenging Analysis of Normalization. Sociologias, No. 20, 150-182. Porto Alegre.

http://www.scielo.br/scielo.php?script=sci arttext\&pid=S1517-45222009000100008\&lng=en\&nrm=iso http://dx.doi.org/10.1590/S1517-45222009000100008

Pinsonneault, A., \& Kraemer, K. (1993). Research Methodology in Management Information Systems. Journal of Management Information Systems - Special Section: Strategic and Competitive Information Systems Archive, 10, 75-105.

Santos, L. H. S. (2009). Heteronormativity and Education. In: C. Penalvo, \& G. Bernardes (Eds.), It Is Difficult to Talk about Sex in School. Porto Alegre: SOMOS.

Silva, T. T. (2000). Cultural Theory and Education-A Critical Vocabulary. Belo Horizonte: Autêntica.

Woodward, K. (2007). Identity and Difference: A Theoretical and Conceptual Introduction. In T. T. Silva, (Ed.), Identidade e diferença: A perspectiva dos estudos culturais (pp. 7-72). Petrópolis: Vozes. 


\section{Submit or recommend next manuscript to SCIRP and we will provide best service for you:}

Accepting pre-submission inquiries through Email, Facebook, LinkedIn, Twitter, etc.

A wide selection of journals (inclusive of 9 subjects, more than 200 journals)

Providing 24-hour high-quality service

User-friendly online submission system

Fair and swift peer-review system

Efficient typesetting and proofreading procedure

Display of the result of downloads and visits, as well as the number of cited articles

Maximum dissemination of your research work

Submit your manuscript at: http://papersubmission.scirp.org/ 